\title{
THE OCCURRENCE OF THE CADENAT'S ROCKFISH, SCORPAENA LOPPEI (ACTINOPTERYGII: SCORPAENIFORMES: SCORPAENIDAE), IN THE EASTERN AEGEAN SEA
}

\author{
Halit FILIZ ${ }^{1 *}$, Sercan YAPICI ${ }^{1}$, S. Can AKCINAR ${ }^{2}$, Efe ULUTURK ${ }^{2}$, \\ H. Zeynep DARDERE ${ }^{2}$, and Mustafa ERDEM ${ }^{1}$ \\ ${ }^{1}$ Mugla University, Faculty of Fisheries, 48000 Kötekli, Mugla, Turkey \\ ${ }^{2}$ Ege University, Faculty of Fisheries, Department of Hydrobiology, 35100, Bornova, Izmir, Turkey
}

Filiz H., Yapici S., Akcinar S.C., Uluturk E., Dardere H.Z., Erdem M. 2010. The occurrence of the Cadenat's rockfish, Scorpaena loppei (Actinopterygii: Scorpaeniformes: Scorpaenidae), in the eastern Aegean Sea. Acta Ichthyol. Piscat. 40 (1): 75-78.

\begin{abstract}
One specimen of the Cadenat's rockfish, Scorpaena loppei Cadenat, 1943 (Scorpeanidae), was caught off Marmaris (eastern Aegean Sea, Turkey) on 27 December 2008 by bottom trawl net. The specimen was 56.15 $\mathrm{mm}$ total length. S. loppei is evidently rare in the Aegean Sea than it is in the western Mediterranean.
\end{abstract}

Keywords: Scorpaena loppei, occurrence, eastern Aegean Sea, Turkey

Scorpaena loppei Cadenat, 1943 is one of the 14 species of Scorpaenidae in the Mediterranean (Quignard and Tomasini 2000). This benthic species is distributed in the eastern Atlantic and Mediterranean Sea (Maul 1976, Hureau and Litvinenko 1986, Bauchot 1987, Golani et al. 2006). It is more abundant in the western Mediterranean, where it is found around Balearic Islands (Merella et al. 1997), in Gulf of Lions (France) (Gaertner et al. 1998), off the coast of Botricello (south-eastern Italian coast, Ionian Sea) at 30 m (Matarrese et al. 1996), the Italian side of Adriatic Sea between 10-50 m (Ungaro et al. 1999), on the Catalan coast between 22-548 m (Spain) (Demestre et al. 2000), and in the Adriatic Sea (Dulčić and Lipej 2002). In the Adriatic it is relatively rare (Dulčić and Lipej 2002). Although it is more common in the western Mediterranean, occurrence of the species in the eastern Mediterranean is considered very rare (Golani 2005, Golani et al. 2006). An early record from Cyprus was given by Fröiland (1972).

Within the Aegean Sea, the occurrence of S. loppei has been well documented and more reliable in Greek territorial waters (Economidis 1973, Kasparis 1976, Papaconstantinou 1988, Labropoulou and Papaconstantinou 2000). However, knowledge regarding its presence in Turkish waters has been uncertain. Akşrray (1987) reported a specimen from Turkish waters, but provided no precise depth or locality information. Based upon the Akşıray (1987) record, this species was included in an early checklist of Turkish fishes (Bilecenoglu et al. 2002). However, it was not included in a recent ichthyofauna checklist of Turkish waters (Fricke et al. 2007). More recently Keskin and Eryllmaz (2008) recorded this "doubtful" fish based on two specimens caught in the Mersin-Taşucu Bay for both Turkish seas and Mediterranean coasts of Turkey. Herein, we provide reliable information about the occurrence of $S$. loppei in eastern Aegean Sea coast of Turkey.

On 27 December 2008, one specimen of S. loppei was captured during the bottom trawl by the commercial fishing vessel off Marmaris Bay (eastern Aegean Sea, Turkey, Fig. 1). The specimen was fixed in 5\% formaldehyde solution. The species identification was aided by guidelines provided by Eschmeyer (1969), Whitehead et al. (1986), and Bauchot (1987). The specimen is deposit-

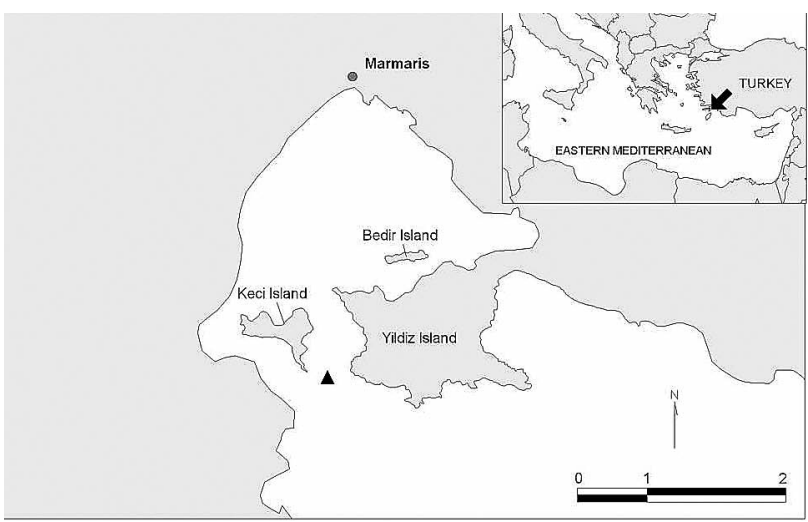

Fig. 1. Area where the studied specimen of Scorpaena loppei was captured 
ed in the Museum of Faculty of Fisheries, Mugla and meristic characters were counted under the reflected University (catalogue number MUSUF/PIS-2008-1). light of a stereomicroscope.

Morphometric characters were measured to the nearest This species was collected as part of a survey carried out $0.01 \mathrm{~mm}$ using digital callipers (Table 1). The specimen in the Marmaris Bay (eastern part of the Aegean Sea), an was weighed (as fresh) to the nearest $0.01 \mathrm{~g}$ digital scales affected area by industrial trawling fisheries. It was taken at

Table 1

Measurements [mm], counts, and rations of S. loppei; present study

\begin{tabular}{lcc}
\hline Parameter & & Value \\
\hline Number of specimen & $n$ & 1 \\
Total Length & TL [mm] & 56.15 \\
Standard Length & SL [mm] & 44.90 \\
Maximum Body Depth/SL & MBD/SL & 31.02 \\
Head Length/SL & HL/SL & 43.74 \\
Snout Length/HL & SnL/HL & 24.69 \\
Snout to Dorsal fin/SL & Sn-D/SL & 37.68 \\
Snout to Pectoral fins/SL & Sn-PEC/SL & 42.18 \\
Snout to Pelvic fin insertion/SL & Sn-PEL/SL & 43.45 \\
Snout to Anal fin base/SL & Sn-A/SL & 65.06 \\
Interorbital Distance/HL & ID/HL & 19.40 \\
Eye Diameter & ED/HL & 27.09 \\
Dorsal rays count & D & XII + 9 \\
Anal rays count & $\mathrm{A}$ & III +5 \\
Pectoral rays count & $\mathrm{P}$ & 18 \\
Pelvic rays count & $\mathrm{PE}$ & $\mathrm{I}+5$ \\
\hline
\end{tabular}
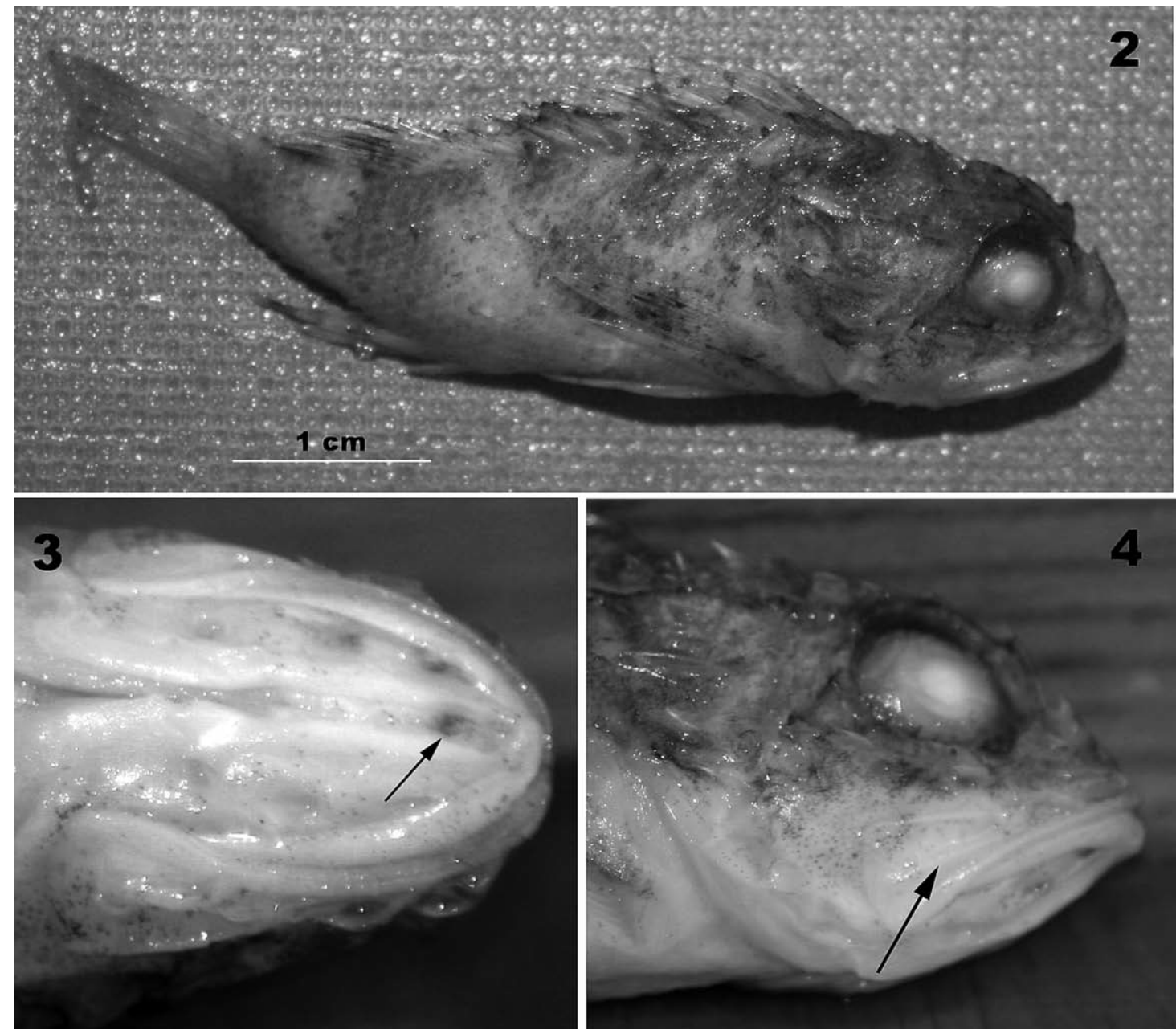

Figs. 2-4. Scorpaena loppei, $56.15 \mathrm{~mm}$ TL, captured in Marmaris Bay (eastern Aegean Sea); Fig. 2. General view; Fig. 3. head below view; Fig. 4. maxilla 
a depth $65-70 \mathrm{~m}$ on a muddy bottom using a conventional bottom trawl net of $24 \mathrm{~mm}$ cod-end mesh size. Two hauls in same day were carried out from dawn to dusk and haul durations ranged from 1 to $3 \mathrm{~h}$. The vessel speed was maintained at 2.2-2.5 knots. The specimen was found in the codend.

Diagnosis: Body moderately compressed; head large; maxilla with a characteristic longitudinal crest; snout shorter than orbit diameter; preorbital bone with 2 spines over maxilla, first is very blunt, second is long and curved to rear; suborbital ridge with 4 spinous points; upper posttemporal spine present. Occipital pit present. Tentacles on head and body poorly developed. Dorsal fin rays XII +9; anal fin rays III +5 ; pectoral fin rays 18 ; pelvic fin rays I +5 . Scales on body ctenoid; chest, pectoral fin base and head naked; vertical rows of scales 37 ; scales in lateral lines 21-22; gillrakers 15 on the whole first arch. Maximum body depth $31.02 \%$ of SL; head length $43.74 \%$ of SL; snout length $24.69 \%$ of head length; eye diameter $27.09 \%$ of head length (Table 1 and Fig. 2).

Body colour uniformly pink with many black spots; a dark spot on spinous dorsal fin between spines 6 and 9 and fins dusky. All counts and measurements agree with descriptions given by Eschmeyer (1969) and Hureau and Litvinenko (1986). S. loppei can be easily distinguished from all other Mediterranean scorpionfishes by the anterior mandibular pores which are united a single opening (Fig. 3) and presence of maxilla with a longitidunal crest (Fig. 4). S. loppei is a small species; Tortonese (1975) reported maximum length $120 \mathrm{~mm}$, Hureau and Litvinenko (1986) $100 \mathrm{~mm}$, Bauchot (1987) $150 \mathrm{~mm}$ and Golani et al. (2006) between 50-100 mm. The species occurs on muddy sand and gravel, generally at depths between 50 and $300 \mathrm{~m}$ (Bauchot 1987, Froese and Pauly 2009). S. loppei feeds mainly with crustaceans (Hureau and Litvinenko 1986) and fish (Golani et al. 2006).

Although the occurrence of $S$. loppei in Greek Aegean waters (Labropoulou and Papaconstantinou 2000) is well documented, the species has not been recorded from the other parts of the Aegean Sea. This is the first record of this species from the Turkish Aegean waters. The rarity of $S$. loppei in the Aegean Sea may be related to its low population density or low capture rate caused by its small size (max. $15 \mathrm{~cm}$ ) (Eschmeyer and Dempster 1990), as well as its body shape and coloration which could be confused with small specimens of other similar species (e.g., S. notata).

\section{ACKNOWLEDGEMENTS}

We would like to thank anonymous referees for the revision of the manuscript. We would like to thank Dr. Bahadir Onsoy for helping us to take and process the photographs.

\section{REFERENCES}

Akşıray F. 1987. Türkiye Deniz Balıkları ve Tayin Anahtarı. [Marine fishes of Turkey and key to species.]: Istanbul Üniversitesi Rektörlüğü Yayınları, Istanbul. [In Turkish.]

Bilecenoglu M., Taskavak E., Mater S., Kaya M. 2002. Checklist of the marine fishes of Turkey. Zootaxa 113: 1-194.
Bauchot M.-L. 1987. Poissons osscux. Pp. 891-1421. In: Fischer W., Bauchot M.-L., Schneider M. (eds.) Fiches FAO d'identification pour les besoins de la péche Méditerranée et mer Noire. Zone de Péche 37. Révision I. Vol. 2. FAO, Rome.

Demestre M., Sánchez P., Abelló P. 2000. Demersal fish assemblages and habitat characteristics on the continental shelf and upper slope of the north-western Mediterranean. Journal of Marine Biology Associated of the United Kingdom 80 (6): 981-988. DOI: 10.1017/S0025315400003040.

Dulčić J., Lipej L. 2002. Rare and little-known fishes in the eastern Adriatic during last two decades (1980-2001). Periodicum Biologorum 4 (2): 185-194.

Economidis P.S. 1973. Catalogue of the fishes of Greece. Hellenic Oceanology and Limnology, Praktika of Institute of Oceanology and Fishing Research 11: 421-598.

Eschmeyer W.N. 1969. A systematic review of the scorpionfishes of the Atlantic Ocean (Pisces, Scorpaenidae). Occasional papers of the California Academy of Sciences No. 79.

Eschmeyer W.N., Dempster L.J. 1990. Scorpaenidae. Pp. 665-679. In: Quero J.C., Hureau J.C., Karrer C., Post A., Saldanha L. (eds.) Check-list of the fishes of the eastern tropical Atlantic (CLOFETA). Vol. 2. JNICT, Lisbon; SEI, Paris; and UNESCO, Paris.

Fricke R., Bilecenoglu M., Sari H.M. 2007. Annotated checklist of fish and lamprey species (Gnathostomata and Petromyzontomorphi) of Turkey, including a Red List of threatened and declining species. Stuttgarter Beiträge zur Naturkunde, Serie Biologie A 706: 1-172.

Froese R., Pauly D. (eds.) 2009. FishBase. [version 01/2009] http://www.fishbase.org.

Fröiland Ö. 1972. Fishes of the family Scorpaenidae from Cyprus, including three new records. Bulletin - Sea Fisheries Research Station (Haifa) 59: 5-16.

Gaertner J.C., Chessel D., Bertrand J. 1998. Stability of spatial structures of demersal assemblages: a multitable approach. Aquatic Living Resources 11 (2): 75-85. DOI: 10.1016/S0990-7440(98)80063-6.

Golani D. 2005. Checklist of the Mediterranean fishes of Israel. Zootaxa 947: 1-90.

Golani D., Öztürk B., Başusta N. 2006. The Fishes of the Eastern Mediterranean. Turkish Marine Research Foundation, Istanbul, Turkey.

Hureau J.-C., Litvinenko N.I. 1986. Scorpaenidae. Pp. 1211-1229. In: Whitehead P.J.P., Bauchot M.-L., Hureau J.-C., Nielsen J., Tortonese E. (eds.) Fishes of the north-eastern Atlantic and the Mediterranean. Vol. 3. UNESCO, The Chaucer Press, Paris.

Kasparis P. 1976. New fish records from the Greek part of the Ionian Sea. Revue des Travaux de l'Institut des Pêches Maritimes 40 (3-4): 627-628.

Keskin Ç., Eryılmaz L. 2008. The presence of Scorpaena loppei (Osteichthyes: Scorpaenidae), in the Turkish Seas. Marine Biodiversity Records (JMBA 2 - Biodiversity Records) (6235): 1-2. DOI: 10.1017/S1755267208000341, http://www.mba.ac.uk/jmba/pdf/6235.pdf.

Labropoulou M., Papaconstantinou C. 2000. Community structure of deep-sea demersal fish in the North Aegean Sea 
(northeastern Mediterranean). Hydrobiologia 440 (1-3): 281-296. DOI: 10.1023/A:1004199917299.

Matarrese A., D'Onghia G., Tursi A., Basanisi M. 1996. New information on the Ichthyofauna of the south-eastern Italian coasts (Ionian Sea). Cybium 20 (2): 197-211.

Merella P., Quetglas A., Alemany F., Carbonell A. 1997. Length-weight relationship of fishes and cephalopods from the Balearic Islands (western Mediterranean). Naga. ICLARM Quarterly 20 (3-4): 66-68.

Maul G.E. 1976. The fishes taken in bottom trawls by R.V. Meteor during the 1967 seamounts cruises in the Northeast Atlantic. Meteor Forschungsergebnisse: Reihe 22: 1-69.

Quignard J.P., Tomasini J.A. 2000. Mediterranean fish biodiversity. Biologia Marina Mediterranea 7 (3): 1-66.

Papaconstantinou C. 1988. Fauna Graeciae. IV. Pisces. Check-list of marine fishes of Greece. Athens, Greece: National Centre for Marine Research, Hellenic Zoological Society, Athens.
Tortonese E. 1975. Fauna D'Italia, Osteichthyes (Pesci ossei). Parte prima. Edizioni Calderini, Bologna.

Ungaro N., Marano C.A., Marsan R., Martino M., Marzano M.C., Strippoli G., Vlora A. 1999. Analysis of demersal species assemblages from trawl surveys in the south Adriatic Sea. Aquatic Living Resources 12 (3): 177-185. DOI: 10.1016/S0990-7440(00)88469-7.

Whitehead P.J.P., Bauchot M.-L., Hureau J.-C., Nielsen J., Tortonese E. (eds.) 1986. Fishes of the north-eastern Atlantic and the Mediterranean. UNESCO, Paris.

Received: 6 May 2009

Accepted: 9 July 2009

Published electronically: 25 June 2010 